\title{
Curriculum flexibility in a blended curriculum
}

\author{
Herma Jonker \\ Windesheim University of Applied Sciences; University of Amsterdam
}

\author{
Virginie März \\ Université catholique de Louvain
}

Joke Voogt

University of Amsterdam; Windesheim University of Applied Sciences

\begin{abstract}
This study offers insights into the processes that play a role in realising curriculum flexibility. Curriculum flexibility is conceptualised in terms of adaptability and accessibility of the curriculum to students' needs and capabilities. To realise curriculum flexibility, the teacher education institution in this study designed a blended curriculum with face-to-face and online components. This flexible curriculum aimed at increasing student enrolment and allowing for variety in students' graduation portfolios. Through semi-structured interviews with 10 teacher educators, conditions that could foster or hinder the realisation of flexibility were investigated. Results indicate that different contextual, teacher-, and student-related conditions were perceived to affect (further) curriculum flexibility. Furthermore, teacher educators identified several challenges related to these influential conditions, which were recognised as tensions. Based on a discussion of these findings, recommendations for research and practice are given.
\end{abstract}

Implications for practice or policy:

- Design teams can use the flexibility matrix to thoroughly think through what the concept of flexibility means in their context and operationalize it unambiguously.

- Design teams should organize meetings with all stakeholders about the intentions of a flexible blended curriculum and its rationale to prevent the development of disconnected views.

- Teachers need to be facilitated and supported to function appropriately in a flexible blended curriculum.

Keywords: curriculum flexibility; blended curriculum, collaborative design; curriculum implementation, perceived curriculum; qualitative research; case study research

\section{Introduction}

Due to continual (eg., technological) developments in society and the increasingly dynamic nature of (eg., international) markets (Redecker et al., 2010), higher education needs to deliver students who are agile enough to adapt to these changes (Organisation for Economic Cooperation and Development, 2010). Lifelong learning is necessary, and educational institutions are expected to offer learning opportunities adapted to a variety of learners (Carlsen, Holmberg, Neghina, \& Owusu-Boampong, 2016; UNESCO, 2009). These opportunities apply to "traditional" students and "non-traditional" students (e.g., working students, students with a family, students with disabilities) (Morgan, 2013). In the past few years, higher education has faced a student influx characterised by an increase in student diversity (Carlsen et al., 2016), indicating the need for more responsive and personalised curricula that tailor education to students' needs, strengths, and interests. Many educational institutions address these needs by designing a flexible curriculum (Hill, 2006; Organisation for Economic Cooperation and Development, 2010). A blended curriculum is often regarded as a good way to organise this flexibility in a curriculum; however, results so far have not substantiated this claim (Jones \& Lau, 2010).

Research has shown that the implementation of a curriculum innovation often results in varied, and not always firmly embedded, practices by teachers (Coburn, Russell, Kaufman, \& Stein, 2012). How teachers experience a curriculum innovation and the degree to which they implement change are determined by 
sense-making processes (Luttenberg, Van Veen, \& Imants, 2013). Research on the design and implementation of flexible blended curricula has shown that flexibility can be impaired by what teachers are able, or willing, to provide (Tucker \& Morris, 2011), and that teachers' conceptions and beliefs strongly relate to what is done in practice (Gerbic, 2011). Nevertheless, research about teachers' perceptions in the context of flexible and blended curricula is still rather limited (Halverson, Graham, Spring, Drysdale, \& Henrie, 2014; Tucker \& Morris, 2011), let alone regarding the combination: flexibility via a blended curriculum. However, such research is most needed when it comes to articulating the views and concerns of teachers (Tucker \& Morris, 2011) who have to function in a blended curriculum (Halverson et al., 2014). This study addresses this gap and aims to shed light on what makes realising flexibility in a blended curriculum difficult from a teacher's point of view.

\section{Theoretical framework}

\section{Curriculum flexibility}

Higher education institutions are increasingly faced with student diversity, with respect to age, domicile, cultural background, personal and professional experiences, motivation, approach to studying, digital literacy, and/or prior education (Severiens, Wolff, \& Van Herpen, 2014). This increased student diversity calls for a curriculum that adapts to and is accessible for students with different needs and capabilities (Rao \& Meo, 2016) - what is often called a flexible curriculum. With a flexible curriculum, learners are provided with more opportunities to regulate their learning process and the learning environment (Collis \& Moonen, 2001; Hill, 2006). Cheong (2013) argued that "the nature of 'flexibility' revolves around learners: what choices are available and how they affect their learning" (p. 2).

According to Tucker and Morris (2011), a flexible curriculum can be positioned anywhere along a continuum with flexible curricula at the one end and traditional fixed curricula at the other. This means that there are degrees of flexibility. In this study, we follow Tucker and Morris' (2011) statement that the flexibility of a curriculum can become visible in terms of what learning entails, and how, where, and when it occurs. Flexibility in the where and when of learning is a precondition for including everyone in times of increased social mobility (Carlsen et al., 2016). A curriculum that offers students the opportunity to decide where and when they learn seems attractive to non-traditional students and students at distant locations (Carlsen et al., 2016; Hill, 2006). The degree to which the curriculum is accessible for all refers to the accessibility dimension of the curriculum. Flexibility in the what and how of learning is perceived as necessary because students have different learning needs, which influence the teaching and learning process. Furthermore, society expresses different expectations for education. The degree to which the curriculum can be adapted to the needs of students and society refers to the adaptability dimension of the curriculum (Table 1).

Table 1

\begin{tabular}{|c|c|c|c|c|}
\hline $\begin{array}{l}\text { Focus } \\
\text { (Carlsen et al., } \\
\text { 2016; Hill, } \\
\text { 2006) }\end{array}$ & $\begin{array}{l}\text { Assumptions } \\
\text { (Tucker \& } \\
\text { Morris, 2011; } \\
\text { Willems, } \\
\text { 2005) }\end{array}$ & $\begin{array}{l}\text { Flexibility (Tucker } \\
\text { \& Morris, 2011) }\end{array}$ & $\begin{array}{l}\text { Curriculum } \\
\text { elements (Van } \\
\text { den Akker, } \\
2010 \text { ) }\end{array}$ & $\begin{array}{l}\text { Examples (Nikolov et al., } \\
\text { 2018; Tucker \& Morris, } \\
\text { 2011) }\end{array}$ \\
\hline $\begin{array}{l}\text { Accessibility } \\
\text { Touches upon } \\
\text { legal, }\end{array}$ & \multirow[t]{2}{*}{$\begin{array}{l}\text { Organizational } \\
\text { responsiveness }\end{array}$} & Where Location & $\begin{array}{l}\text { learning } \\
\text { environment }\end{array}$ & $\begin{array}{l}\text { Inside/outside classroom/ } \\
\text { school, use of } \\
\text { building/rooms, } \\
\text { traditional/blended/digital. }\end{array}$ \\
\hline $\begin{array}{l}\text { organizational } \\
\text { and } \\
\text { administrative } \\
\text { aspects of } \\
\text { education. }\end{array}$ & & When Time & time & $\begin{array}{l}\text { Pace, duration, time span, } \\
\text { moment, sequence, } \\
\text { synchronous/asynchronous } \\
\text { communication, fixed or } \\
\text { loose deadlines. }\end{array}$ \\
\hline
\end{tabular}




\begin{tabular}{|c|c|c|c|c|c|}
\hline \multirow{3}{*}{$\begin{array}{l}\text { Adaptability } \\
\text { Touches upon } \\
\text { psychological, } \\
\text { pedagogical, } \\
\text { and didactical } \\
\text { aspects of } \\
\text { education". }\end{array}$} & $\begin{array}{l}\text { Programmatic } \\
\text { responsiveness }\end{array}$ & What & Content & $\begin{array}{l}\text { - } \text { aims \& } \\
\text { objectives } \\
\text { - content } \\
\text { - assessment }\end{array}$ & $\begin{array}{l}\text { Educational form, levels, } \\
\text { graduation portfolios, } \\
\text { uniform/personalized, levels } \\
\text { and structure of instruction, } \\
\text { choice in topics/courses, } \\
\text { forms of assessment. }\end{array}$ \\
\hline & $\begin{array}{l}\text { Pedagogical } \\
\text { responsiveness }\end{array}$ & How & Pedagogies & $\begin{array}{l}\text { - learning } \\
\text { activities } \\
\text { - } \text { materials/ } \\
\text { resources } \\
\text { - grouping } \\
\text { - teacher roles }\end{array}$ & $\begin{array}{l}\text { (More) open-ended or } \\
\text { (more) closed-ended, } \\
\text { learning styles, amount of } \\
\text { guidance, product and task } \\
\text { options in assignments, high } \\
\text { and low (or no) tech } \\
\text { materials, fixed or flexible } \\
\text { individual/small } \\
\text { group/whole-class, } \\
\text { individually/collaboratively, } \\
\text { student- \& teacher- } \\
\text { centeredness, solo or co- } \\
\text { teaching }\end{array}$ \\
\hline & & & & $\begin{array}{l}\text { All elements } \\
\text { relating to the } \\
\text { rationale. }\end{array}$ & $\begin{array}{l}\text { Reasons for flexibility? } \\
\text { Interdependencies between } \\
\text { elements. }\end{array}$ \\
\hline
\end{tabular}

Note. Also often operates legally within a policy framework with objectives and (standardized) assessments.

\section{Blended curriculum}

A blended curriculum is often used for realising curriculum flexibility (Boelens, De Wever, \& Voet, 2017; Graham, 2006). A blended curriculum can be defined simply as a deliberate mix of digital and face-to-face (f2f) education, in order to stimulate and support learning (Boelens et al., 2017; Gerbic, 2011). Blended education may be embraced by a whole institution, it may be the educational form of a curriculum, the design of one/some of the courses, or a blend may be solely present in learning activities (Graham, 2006). The designs of blended curricula can therefore be positioned on a continuum, anywhere between completely $\mathrm{f} 2 \mathrm{f}$ curricula on the one hand and completely online curricula on the other (Graham, Woodfield, \& Harrison, 2013), but typically some of the teaching and learning is accomplished in a digital environment. A great variety exists in blended designs (Gerbic, 2011; Graham et al., 2013; Jones \& Lau, 2010), regarding the sequence of $\mathrm{f} 2 \mathrm{f}$ and online parts (Boelens et al., 2017); the aims and functions of the $\mathrm{f} 2 \mathrm{f}$ and online parts (Boelens et al., 2017; Graham, 2006); or who controls the exact blend: the designer, the teacher, or the student (Boelens et al., 2017; Graham, 2006).

Especially because of its digital component(s), a blended curriculum can offer flexibility without losing the human richness of $\mathrm{f} 2 \mathrm{f}$ contacts (Graham, 2006). Scholars agree that information and communication technologies (ICTs) play an important role in realising curriculum flexibility, because they make choices, alternatives, and variety realisable and manageable and can bridge distance and time (Carlsen et al., 2016; Hill, 2006). In relation to the flexible aspects of a curriculum (Table 1), the digital component of the blended curriculum can present the content in different ways and on different levels, can offer choices in, for instance, learning activities and materials - thus realising programmatic and pedagogical responsiveness (what and how of learning) to students' learning needs. Also, the digital component can bring parts of education to distant locations and provide students the opportunity to study at any time they prefer - thus realising organisational responsiveness to include all students (where and when of learning). However, it is a widespread misconception that digital technologies provide flexibility in themselves. Flexibility is primarily connected to pedagogies (Nikolov, Lai, Sendova, \& Jonker, 2018). In particular, blended education seems to fit well with student-centred learning approaches (cf. Smits, 2012). In such approaches, students and their needs are central when decisions about teaching and learning processes are made (cf. Willems, 2005), and consequently, the teacher moves from the center of interactions towards being a coach (Baran, Correia, \& Thompson, 2011). 


\section{Challenges in realising curriculum flexibility in a blended curriculum}

Flexibility assumes certain organisational conditions and readiness of the educational context, student, and teachers (Willems, 2005). In the following, several challenges in this regard will be presented.

\section{Contextual challenges}

In their report about policy guidelines for inclusive education, UNESCO (2009) determined several preconditions regarding prioritisation, fragmentation, and budgets, among others. Often, educational systems do not allow enough flexibility in procedures, hindering successful implementation of a flexible curriculum through blended education. For example, in the Netherlands, making time flexible is restricted by legal guidelines; in Wales, validation procedures made it impossible to remove exams as a form of assessment (Jones \& Lau, 2010). Furthermore, a blended curriculum assumes a smoothly functioning technological infrastructure, on the part of both the institution and the students. Willems (2005), for instance, signalled issues around connectivity and hardware and software that hindered flexible opportunities. Another set of challenges arises around agenda setting. Disconnected views of flexibility often exist among the different stakeholders, caused by a mixture of multiple needs (Tucker \& Morris, 2011; Willems, 2005). Management often starts from an economic point of view (e.g., cost effectiveness, growth) while teachers start from a pedagogical point of view (e.g., learner outcomes, student satisfaction). This tension often results in a lack of clarity about the reasons for flexibility and the blended form, and a rationale that is not well articulated and not translated into design guidelines for course development, and/or not beneficial for or supported by all stakeholders (Graham et al., 2013; Severiens et al., 2014; Tucker \& Morris, 2011; Willems, 2005). When the rationale is not shared, problems can be expected with the alignment between the intended, formal, implemented, and attained curriculum (Van den Akker, 2010).

\section{Teacher-related challenges}

With regard to the teacher, challenges arise in relation to course development and lesson enactment. Two challenges can be recognised: there is a lack of a clear focus on pedagogies and learning theories that are suitable for a flexible educational context, and teachers who do not hold a student-centered view need to be supported to align their pedagogical beliefs and practices with an approach that supports learners in their learning process (Nikolov et al., 2018). Teachers coming from a f2f context need to rethink their assumptions about teaching and learning when online teaching is required (Baran et al., 2011; Gerbic, 2011).

First, a blended design adds complexity to course development because, according to Gerbic (2011), decisions must be made about what should best be done in each part of the blend, and how the parts should be connected in order to unify the course. In particular, according to Demedts, Raes, Spittaels, Lust, and Van Puyenbroeck (2015), teachers must integrate their technological pedagogical and content knowledge (Mishra \& Koehler, 2006) to design a meaningful blend. Furthermore, teachers differ in their opinion as to whether personal contacts are necessary for the learning process and/or student satisfaction. Moreover, teachers should develop their courses so that students' needs and capabilities are taken into account. However, teachers are not very well prepared for developing for student diversity (Severiens et al., 2014).

Scholars agree that the co-existence of two pedagogical contexts ( $\mathrm{f} 2 \mathrm{f}$ and digital) in a blended curriculum (Gerbic, 2011) requires a more comprehensive, complex, and flexible repertoire of teaching strategies in order to improve students' learning processes in both contexts (Baran, Correia, \& Thompson, 2013). Teachers must learn to be visible also in the online part of the blend, in order to fulfil the cognitive, affective, and social elements of a teacher's task (cf. Baran et al., 2011), and/or must learn how to cope with a greater transactional distance (Boelens et al., 2017) and the omnipresence of interactions (Conceição, 2006). The challenge is how to interact effectively online so that the different teaching roles are adequately expressed and lead to student satisfaction and learning (Smits \& Voogt, 2017). For instance, teachers struggle with their moderator role and tend to forget the social side in their online activities (Smits, 2012). Furthermore, ICT skills need to be part of a teacher's repertoire in flexible blended contexts, especially the higher-level software skills (e.g., knowing how to socialise digitally and facilitate communication and group work as well as creativity; Hampel \& Stickler, 2005) in order to facilitate the learning processes in the online parts of the blend. Generally, teachers need support in the design, implementation, and enactment of a flexible blended curriculum (Tucker \& Morris, 2011; Willems, 2005). 
Student-related challenges

On the students' part, self-regulation, study, and technological skills are crucial for functioning successfully in a flexible context (Boelens et al., 2017). When a student-centred approach is enacted, a student is expected to shift from a passive student role towards an active one, which implies turning from being a knowledge consumer towards becoming a knowledge constructor (Siemens, 2005). Research has frequently found that flexibility and learner control are especially beneficial for high achievers and students who possess study skills (Owston, York, \& Murtha, 2013). When students have limited self-regulatory skills, flexibility may also lead to procrastination (Hoy \& Tarter, 2011). Often, the choices students make and the study- and self-regulation skills that are needed to function in a flexible blended curriculum are not aligned (Graham, 2006). In the context of a blended curriculum, the need for technological skills is commonly recognised (Boelens et al. (2017). Students encounter other forms of interaction, especially in the online part of the program, such as participating in synchronous or asynchronous lessons and forum discussions, collaborating in a digital community, or being digitally assessed. In general, students need support in order to function in flexible blended curricula.

\section{Context of the study}

This study took place within a teacher training college, which we are calling Waterfront College, in the Netherlands. Waterfront College offers a four-year program in higher education, which prepares students to become a technical teacher in (pre-)vocational education.

Waterfront College faced the challenges that an increase in student enrollment was necessary, and a variety of graduation portfolios were expected by receiving schools and industry. It was decided that a flexible curriculum could address these needs. Starting in the academic year 2014-2015, a teacher design team at Waterfront College redesigned the common $\mathrm{f} 2 \mathrm{f}$ curriculum as a blended curriculum. The blended curriculum design was built on a fixed structure; courses were organised in weekly lessons, alternating between $\mathrm{f} 2 \mathrm{f}$ and online. The digital part of the blend consisted of a repository for curriculum materials in an electronic learning environment and online lessons through Adobe Connect, enabling synchronous communications. How to fill the blended structure for their own courses (i.e., what was done in the $\mathrm{f} 2 \mathrm{f}$ part and what in the online part) was up to each teacher educator. As a result, the actual blended structure showed differences among the courses.

As preparation for this study, the flexibility of the formal curriculum was examined in a product scan: The documents from a random selection of courses $(n=14)$ were analysed by the teacher educators of Waterfront College. The product scan showed that flexibility was present in different degrees (see also Jonker, März, \& Voogt, 2018). More specifically, in terms of flexible aspects of a curriculum (see Table 1), it appeared that organisational responsiveness was barely realised because the curriculum's accessibility (where and when of learning) was limited by the choice for synchronous communication in the digital part of the blend; programmatic responsiveness (i.e., the curriculum's adaptability regarding the what of learning) was possible in half of the courses, mainly in the curriculum element content allowing for choices students had in the topics that were offered, and barely in the curriculum elements aims/objectives and assessment; and pedagogical responsiveness (the curriculum's adaptability regarding the how of learning) showed the highest amount of flexibility. Students could choose, for instance, between three different, but comparable, assignments; the literature that was used contained several titles from which the students should use a certain number; or students might decide for themselves to sign up, or not, for supplementary instruction. However, information about pedagogies was not present in all courses.

\section{Research questions}

The main research question that guided this study was: How do teacher educators perceive the enactment of flexibility in the blended curriculum? This question was divided into two sub-questions, namely:

RQ1: What conditions do teacher educators perceive as necessary for the enactment of flexibility in a blended curriculum?

RQ2: What challenges do teacher educators perceive during the enactment of flexibility in the blended curriculum? 


\section{Methods}

To develop an in-depth understanding of teachers' perspectives, we opted for a single case study (Halverson et al., 2014; Tucker \& Morris, 2011). Participants shared their experiences regarding the concept of curriculum flexibility and commonalities were synthesised (Saldaña, 2011) in order to gain detailed insights into their perceptions of the phenomenon of curriculum flexibility. The case study included all teacher educators who had experience with the implementation of Waterfront's blended curriculum $(n=10)$.

\section{Instruments and data collection}

Flexibility is conceptualised in terms of accessibility and adaptability. Table 2 provides the operationalisation of the concepts and their relation to the intentions of the innovation.

Table 2

Innovation intentions and their operationalisation

\begin{tabular}{|c|c|c|c|}
\hline Intentions & Criterion & Definition & Flexible aspects \\
\hline $\begin{array}{l}\text { Increase student } \\
\text { numbers } \\
>\text { Attract more } \\
\text { students and } \\
\text { students on a distant } \\
\text { location. }\end{array}$ & Accessibility & $\begin{array}{l}\text { An educational setting } \\
\text { in which students can } \\
\text { decide for themselves } \\
\text { where and when they } \\
\text { learn. }\end{array}$ & $\begin{array}{l}\text { Where (learning environment): the } \\
\text { location where formal educational } \\
\text { activities take place. } \\
\text { When (time): the duration, pace, } \\
\text { sequence, start and completion } \\
\text { dates of educational activities. }\end{array}$ \\
\hline \multirow{2}{*}{$\begin{array}{l}\text { Different needs of } \\
\text { students and field } \\
>\text { Offer variety in } \\
\text { graduation } \\
\text { portfolios. }\end{array}$} & \multirow[t]{2}{*}{ Adaptability } & \multirow{2}{*}{$\begin{array}{l}\text { An educational setting } \\
\text { that can handle diversity } \\
\text { with regard to individual } \\
\text { students' learning needs } \\
\text { and needs of the field } \\
\text { with regard to what is } \\
\text { learned and how. }\end{array}$} & $\begin{array}{l}\text { What (content): the } \\
\text { aims/objectives, content, and } \\
\text { assessments of (parts of) the } \\
\text { curriculum. }\end{array}$ \\
\hline & & & $\begin{array}{l}\text { How (pedagogies): the learning } \\
\text { activities, materials/resources, } \\
\text { grouping, and teacher roles that are } \\
\text { used to support learning processes. }\end{array}$ \\
\hline
\end{tabular}

Data collection took place using individual semi-structured interviews. To prepare for the interview, the participants had received a table with the aggregated results of the product scan (see Context of the study). At the start of the interview, teacher educators were asked to write down their first impressions of the table's information in 10 words. Then, for each flexibility cluster (what, how, where, when), the following questions guided the interview:

- According to you, do the results of the product scan reflect the intentions of the change to the blended curriculum? (If not, did you expect more, or less, flexibility?)

- Is the scan a good representation of what happens in practice? (If not, where do you perceive deviations?)

- Are you satisfied with the extent of flexibility that is realised? If so, why is greater flexibility not necessary; if not, what limits the extent of flexibility?

- Participants were asked to organise their explanations into conditions related to the context, content (program), teachers, and students.

Participants were encouraged to reflect on their answers. The interviews lasted between 30 and 50 minutes and were audiotaped. All participants were informed that the data would be used for research purposes and that participation was voluntary.

\section{Data analysis}

All interviews were transcribed and interpretively coded. The first author took the lead and the co-authors functioned as critical friends. The transcription protocols were divided into text fragments and coded through deductive and inductive coding strategies (Miles \& Huberman, 1994). First, a deductive coding framework was set up. We used Tucker and Morris' (2011) distinction in the what, how, where, and when 
of learning to guide the data coding, because it clearly related to the intentions of the innovation (adaptability, accessibility - left side of Table 1) and provided a way to make flexibility visible (specifications - right side of Table 1). The final framework involved:

- flexibility clusters: the curriculum's adaptability (what, how) and accessibility (where, when) and the corresponding curriculum elements;

- $\quad$ curriculum representations: the curriculum as intended, as documented (formal), and as perceived by the teacher educators (Van den Akker, 2010);

- conditions representing the challenges: context-, content-, teacher- and student-related conditions.

After reading the transcripts inductive codes emerged, which were discussed during meetings and modified based on consensus in the research team. To ensure reliability, (a) the research team then discussed the coding scheme for a uniform interpretation of the codes; (b) two researchers separately coded the same two interviews, compared their codes, and discussed differences until consensus was reached; (c) the remaining transcripts were coded by the first author (see codebook in the Appendix).

Next, data analysis progressed in two phases. In the first phase, the individual teacher educator was taken as the unit of analysis. After we determined the curriculum cluster, element(s), and representation a text fragment referred to, codes for the conditions representing the challenges were assigned to the statements. In the second phase, we looked for systematic differences, similarities, patterns, and processes across the 10 teacher educators. The technique of constant comparative analysis was used (Miles \& Huberman, 1994).

\section{Findings}

In order to understand the findings, it is important to know what the team of teachers perceived to be flexibility in the blended curriculum. Within the team a very diverse picture emerged. Some of the teachers thought flexibility meant taking the varied needs of the receiving schools into account, others described it in terms of adapting education to the learning preferences of students, and still others related flexibility to attracting students that are on a distant location. The following quotes (all names are pseudonyms) illustrate the diversity of the perceptions that existed within the team with regard to flexibility. Flexibility ...

$\ldots$ is about (...) taking prior knowledge of part time students into account. (Nico)

... will not be about the what-question [objectives, content, assessment] - this should be predetermined beforehand. (...) Otherwise you can't guarantee the quality, because you don't know what the purpose of your education is. (Carolien)

... relates to matching education to the needs and preferences of the students and the field. (Inge)

... is not what students want; they like a schedule with what will be done, when, and what is expected of me. (Maarten)

... means we have to adapt our program to the target group and their living conditions. (Kevin)

... in learning environment is necessary for attracting students from all parts of the country. (Tinus)

In other words, within the teacher team no consensus was shown in what flexibility means in the first place, nor how it can become visible in the curriculum.

\section{Necessary conditions for enactment of flexibility in a blended curriculum}

A majority of teacher educators mostly regarded context-, teacher-, and student-related conditions as affecting the enactment of flexibility in the blended curriculum. Content-related conditions were barely mentioned, were diffuse, and lacked a common base. They will therefore be omitted. Table 3 gives an overview of the details (mentioned by at least two teachers) within each factor, matched to the flexibility clusters. 
Table 3

Conditions affecting flexibility $(n=10)$

\begin{tabular}{|c|c|c|c|c|c|c|c|}
\hline \multicolumn{3}{|c|}{ Conditions } & \multirow{2}{*}{$\begin{array}{c}\text { Mentioned } \\
\text { by }\end{array}$} & \multicolumn{4}{|c|}{ Flexibility clusters } \\
\hline & & & & what & how & where & when \\
\hline \multirow{3}{*}{ 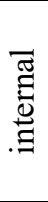 } & $\begin{array}{l}\text { Teacher- } \\
\text { related }\end{array}$ & $\begin{array}{l}\text { conservative or innovative } \\
\text { attitude }\end{array}$ & 10 & $\mathrm{x}$ & $\mathrm{x}$ & $\mathrm{x}$ & $\mathrm{x}$ \\
\hline & & pedagogical \& digital skills & 8 & $x$ & $\mathrm{x}$ & $x$ & $\mathrm{X}$ \\
\hline & & $\begin{array}{l}\text { knowledge about curriculum } \\
\text { flexibility }\end{array}$ & 3 & & $\mathrm{x}$ & & \\
\hline \multirow{8}{*}{ 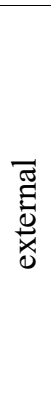 } & $\begin{array}{l}\text { Context- } \\
\text { related }\end{array}$ & $\begin{array}{l}\text { assigned time for } \\
\text { development }\end{array}$ & 7 & $\mathrm{x}$ & $\mathrm{x}$ & $\mathrm{x}$ & $\mathrm{x}$ \\
\hline & & fixed formulated regulations ${ }^{*}$ & 5 & $\mathrm{x}$ & & $\mathrm{x}$ & \\
\hline & & blended structure ${ }^{* *}$ & 5 & & & $\mathrm{x}$ & $\mathrm{x}$ \\
\hline & & pressure accountability $^{*}$ & 3 & & $\mathrm{x}$ & & \\
\hline & & availability rooms/materials* & 3 & & & $\mathrm{x}$ & \\
\hline & Student- & need for structure/clarity & 7 & $\mathrm{x}$ & $\mathrm{x}$ & & $\mathrm{x}$ \\
\hline & related & study skills $^{* * *}$ & 5 & $\mathrm{x}$ & $\mathrm{x}$ & & \\
\hline & & situation of part-time students & 3 & & $\mathrm{x}$ & & \\
\hline
\end{tabular}

\section{Teacher-related conditions}

The teacher educators stressed the importance of teacher-related conditions when it comes to curriculum flexibility, but formulated their perceptions regarding the teacher often as if they were talking about other teachers and not about themselves. First, teachers' attitudes were mentioned by all teacher educators as a factor enabling or hindering curriculum flexibility. More specifically, familiar habits and not being able to let go of the students were perceived as inhibiting curriculum flexibility. Such an attitude often went together with not daring to be innovative. Second, teachers' lack of adequate skills for offering flexibility were frequently mentioned. The teacher educators talked about teachers' pedagogical skills, digital skills, and skills related to curriculum design expertise. Finally, some of the teacher educators referred to teachers' knowledge as affecting the flexibility realised in the how. Insufficient knowledge might hinder enacting flexibility in terms of for instance "just not knowing how to offer flexibility" (Kevin).

\section{Context-related conditions}

Besides teacher-related conditions, the teacher educators frequently referred to the role of context-related conditions in enabling or hindering the successful implementation of a blended curriculum. First, the amount of time that Waterfront College assigned to teacher educators for this innovation was especially emphasised. Teacher educators mentioned that they did not have enough time for (re)designing their courses into the blended form, nor for developing curriculum materials. They also felt that they needed extra time for preparing their online lessons and digital materials. Second, fixed formulated regulations from the university limited the possibilities for curriculum flexibility. Third, the chosen blended structure was perceived to negatively affect the curriculum's accessibility. Finally, teacher educators mentioned the availability of rooms and materials, which is organised in strict schedules with little opportunity to use rooms and other resources at other times.

\section{Student-related conditions}

Students' attitudes and skills were explicitly addressed when teacher educators were asked to think about student-related conditions. First, students' attitudes reflecting a traditional (passive) student role were perceived as hindering curriculum flexibility. Students' attitudes connect to a second student-related condition, namely, students' study skills. These skills were perceived to relate especially to adaptability. According to the teacher educators, in flexible education students need to be able to structure their tasks, make an overview, make plans and work according to them, and study independently. Lack of skills was mainly mentioned for first-year or younger students. In the context of a college with many part-time students, only one of the teacher educators elaborated on the consequences of this specific situation of parttime students in relation to their (possible) needs for flexibility. 


\section{Tensions regarding the enactment of flexibility in the blended curriculum}

The conditions affecting the extent of flexibility appeared to represent specific tensions with regard to the realisation of a flexible blended curriculum. These tensions were often the result of challenges arising between conditions (Table 4).

Table 4

Conditions in relation to challenges and tensions

\begin{tabular}{|c|c|c|}
\hline Conditions & Challenges with regard to & Tension \\
\hline \multicolumn{3}{|l|}{ Teacher-related } \\
\hline $\begin{array}{l}\text { Teachers' } \\
\text { knowledge } \\
\text { Teachers'skills }\end{array}$ & $\begin{array}{ll}\text { - } & \text { suitable pedagogies and } \\
\text { learning theories } \\
\text { - } \\
\text { - } \\
\text { - } \\
\text { developing for diversity } \\
\text { ICT: higher-level skills, self- } \\
\text { efficacy }\end{array}$ & $\begin{array}{l}\text { (1) curriculum fragmentation - curriculum } \\
\text { coherence } \\
\text { (1) curriculum fragmentation - curriculum } \\
\text { coherence } \\
\text { (2) fixed routines - changing demands }\end{array}$ \\
\hline Teachers' attitudes & $\begin{array}{l}\text { beliefs about teaching and } \\
\text { learning }\end{array}$ & $\begin{array}{l}\text { (2) fixed routines - changing demands } \\
\text { (3) offered - intended flexibility }\end{array}$ \\
\hline \multicolumn{3}{|l|}{ Context-related } \\
\hline $\begin{array}{l}\text { Fixed formulated } \\
\text { regulations }\end{array}$ & $\begin{array}{l}\text { - readiness regarding systems } \\
\text { and procedures }\end{array}$ & (4) fixed structures - flexible intentions \\
\hline Blended structure & $\begin{array}{l}\text { rationale about flexibility, } \\
\text { blended form } \\
\text { reasons for flexibility }\end{array}$ & $\begin{array}{l}\text { (5) fixed design blended structure - } \\
\text { flexible needs for accessibility } \\
\text { (6) disconnected views - shared rationale }\end{array}$ \\
\hline \multicolumn{3}{|l|}{ Student-related } \\
\hline $\begin{array}{l}\text { Students' attitudes, } \\
\text { skills }\end{array}$ & $\begin{array}{ll}\text { - } & \text { self-regulation skills, study } \\
\text { skills }\end{array}$ & $\begin{array}{l}\text { (7) students' needs for structure - flexible } \\
\text { education }\end{array}$ \\
\hline
\end{tabular}

Tension 1: Curriculum fragmentation versus curriculum coherence

As described in the introduction to the Findings paragraph, perceptions of flexibility were very diverse within the team of teachers. Whereas a flexible blended curriculum asks for a shared vision regarding the rationale for flexibility, and the development of curriculum elements consistent with this rationale, we found that five teacher educators mentioned that they limited their perceptions of the flexibility that was realised to their own domain or to the courses that they taught themselves. In other words, these teacher educators mainly focused on their domain or course level instead of on the program level. This led to a fragmented perception of the curriculum. For instance, Joost said:

Of course, I can't answer the question [whether the product scan represents what happens in practice] for every course ... It's difficult to say something about the courses of which you don't know the content ... but if I only look at my own courses, the two that are in the table.

The teacher educators who focused on domain or course level showed less awareness of the interdependencies within a curriculum, leading to contradictions. For instance, they subscribed to flexibility with time as a general tenet, but limited flexibility in their own courses by stating that practical work needs real-time supervision and control by the teacher in the workplace - whose presence in the workplace is scheduled according to a lesson table. Such contradictions relate to teacher educators' skills and knowledge, which were perceived to be inadequate. Moreover, fewer of these teacher educators mentioned contextrelated conditions. The focus on their own domain or course may suggest that context-related conditions, such as the limited amount of time for development, were handled within their own specific teaching and learning situation.

Tension 2: Fixed routines versus changing demands

Teacher educators mainly expressed concerns relating to their professional identity, while the change to a flexible blended context called for adaptations, in particular regarding their knowledge and skills, daily routines, and beliefs. This was visible, for instance, in the higher-level ICT skills that are needed and teachers' self-efficacy in using them. Much was demanded of teacher educators' professionalism in 
incorporating the technological changes in their daily practice. Inge, for instance, perceived how difficult the online part of the blend was for some of her colleagues:

The $\mathrm{f} 2 \mathrm{f}$ lessons, we could do that, as teachers. But, the online lessons, when you talk about how to enact those lessons, that was very complex indeed. We have experienced a lot, tried out lots of things ... but, well, we had to get used to the online part ourselves. And then you can't offer those lessons immediately in a flexible way, I think.

Although a basic (optional) workshop about the use of AdobeConnect (synchronous communication tool) was organised, this did not suffice for acquiring the necessary higher-level digital skills. Perceptions of teacher educators who thought that the amount of flexibility was just fine, related to uncertainties about, or feeling uncomfortable with, the blended form of the curriculum. After all, pedagogical decisions related to making courses (more) flexible, or not, were considered part of teacher educators' professionalism. Such a position does not tolerate external influence: "Well, what is said on paper about teacher roles and learning activities will always depend on the teacher. The teacher has his freedom in this regard...He can make things more or less flexible" (Ulrike). Furthermore, beliefs about education affected the flexible blended curriculum. Conceptually, flexibility implies that students control their own learning process to a certain extent, which conflicts with a traditional teacher-centred view. A traditional teacher role emerged, for instance, when teacher educators described how practical courses should be supervised and controlled by a teacher. A traditional attitude is also related to not being innovative. Ulrike, for instance, connected not being innovative with the demands of the innovation:

Talking about the teacher educators, they could prefer certainty, being accustomed to specific activities ... and they could be a little anxious about innovations, or about getting away from the beaten track, or about not complying to the standards of accreditation.

\section{Tension 3: Offered versus intended flexibility}

The intended flexibility regularly clashed with the degree of flexibility a teacher educator was personally willing to offer. All teacher educators thought that, overall, the degree of flexibility in the formal curriculum should have been higher in the light of the intentions of the curriculum innovation. However, a teacher educator's perception about the intentions (just fine, or too little) did not mean that he/she felt automatically satisfied or dissatisfied, respectively, with the achieved flexibility. Teacher educators who thought that more flexibility was intended, but were satisfied with the implemented flexibility, said that the realised flexibility matched what they regarded as appropriate and manageable. Teachers regularly stated that their concerns about time, energy, and workload played a role in realising flexibility. Ulrike was an example: "I, as a teacher, am satisfied, because I don't think flexibility meets the need to decrease a teacher's workload, not per se". These kinds of personal, practical concerns in relation to enacting flexibility indicate that the intended flexibility (thus also the rationale of the blended curriculum) was not supported by all teacher educators.

\section{Tension 4: Fixed structures versus flexible intentions}

Teacher educators identified structures in the context that undermine flexibility. First, the perception was that (external) systems and regulations were still based on a non-flexible educational context, indicating that the context was not (yet) ready for curriculum flexibility. Maarten's discussion of the characteristics of the university's systems illustrated this:

Things like a VOE [format course description], that can only be adapted at very specific moments ... And Educator [grade registration system], in which information can only be managed in certain ways ... These are all restrictions from the university's systems ... these are older systems that can’t simply be changed because they have little flexibility originally.

The teacher educators experienced pressure to follow these procedures to a painstaking extent, caused by the university's response to external validation institutions. They mentioned, among others, the obligation to document everything, in a very detailed form, in prescribed formats, and all this according to a fixed time schedule. Tinus, for instance, mentioned the pressure he felt to document everything, and Ulrike formulated a contradiction between accountability and flexibility: 
One of my regrets is that the graduation course is rather fixed, actually. I think this has to do with the fact that external authorities come to look behind the scenes, and this leads to pressure to do things by the book. So, the system, this university or maybe farther away, the system limits flexibility.

Tension 5: Fixed design of blended structure versus flexible needs for accessibility

The way the blended structure was constructed by Waterfront College was perceived to limit flexibility by restricting the control a student has with regard to the when and where of his/her learning. Choosing synchronous communication limited the accessibility of the blended curriculum because it still demanded a student's presence at fixed moments. Waterfront's blended structure existed of weekly alternating $\mathrm{f} 2 \mathrm{f}$ lessons and online lessons. Flexibility in the where of learning was therefore also rather limited. Kevin reflected about freedom in the learning environment when he said:

When you strive for the learning environment to become more free, I wonder if that connects to a fixed f2f-online structure. Actually, there is still no choice, because, the one week you are at home, maybe at work, well, and the other week you will be at the institution. So, one may ask .... does this chosen blended structure really fit the design guideline about a more flexible learning environment?

Tension 6: Disconnected views versus a shared rationale

The rationale for the blended curriculum left room for varying interpretations. Although teacher educators' perceptions about the curriculum's accessibility were uniform (i.e., "too little flexibility"), perceptions varied considerably with regard to the concept of adaptability. More specifically, some teacher educators related adaptability to taking the varied needs of the receiving schools into account; others thought adaptability was about taking the learning preferences of students into account; still others thought intentions could not be related to the what because the program simply must meet externally validated qualifications, or that Waterfront needs to state clearly what the program stands for in order to assure valid assessments. Inge and Kevin's comments illustrate the varying perceptions in the teachers' team:

I imagine this is a suitable amount of flexibility. I actually think it's pretty much, there's a fairly good amount of flexibility. And there's also variety, some things open, choices, or only a bit framed ... all kinds of variants. (Inge)

I assume that the student population increases when we adapt our program more to the target group and their living conditions... But then I see too many fixed elements. It doesn't make sense, all those fixed elements of the "how". (Kevin)

The contradictory interpretations of flexibility, in particular about adaptability, indicate the existence of disconnected views.

Tension 7: Students' needs for structure versus flexible education

All efforts to offer flexibility seem curious in the light of some teacher educators' perception of their students: namely, as not flexible at all. A majority of the teacher educators mentioned students' needs for clarity, their preferences for certainty and regularity. Maarten described how the need for structure hindered flexibility:

I think students like the fact that there is a schedule that says: We meet each other at that time, and then this is the agenda ... It's the need for structure. And also, they're used to it that way, and actually, that feels quite good for them.

This attitude relates to students' study skills to some extent. Concerns about students' study skills may dissipate over time as students become more experienced. 


\section{Discussion}

\section{Conclusion}

This study focused on the processes that play a role in realising flexibility in a blended curriculum. According to the teacher educators in this study, enactment of flexibility in the blended curriculum was affected by teacher-related, context-related, and student-related conditions. Teacher-related conditions related to teacher educators' attitudes, skills, and knowledge. Context-related conditions that affected flexibility showed that procedures and regulations often impeded flexibility, instead of supporting it. Concerning the student-related conditions, a traditional, passive attitude and insufficient study skills were especially perceived to inhibit curriculum flexibility with regard to its adaptability.

Our study provides insights specifically regarding the fact that challenges concerning the enactment of flexibility in the blended curriculum show themselves in several tensions. These tensions relate to the teachers and the context, as well as the students. First, decisions by teacher educators whose perceptions had a narrow view of the curriculum innovation undermined the coherence of the curriculum as a whole: Decisions were not consistently oriented towards flexibility in all curriculum elements. This was especially problematic because of the large differences in perceptions of flexibility that existed within the team of teachers. Furthermore, the curriculum innovation aiming at a flexible blended curriculum was interpreted from one's own frame of reference instead of the innovation's frame of reference (Ketelaar, Beijaard, Boshuizen, \& den Brok, 2012). The focus on teacher educators' own perspective indicated that aspects of their professional identity were under pressure. In particular, the knowledge, skills, and beliefs of some teacher educators were at odds with the demands of a flexible blended context. In this regard, teachers' technological beliefs and skills are an important pillar regarding flexibility and blended education in particular (cf. Tondeur, Van Braak, Ertmer, \& Ottenbreit-Leftwich, 2017). Second, flexible blended curricula assume flexibility in systems, procedures, and regulations present within the context, but in this study the context in reality included non-flexible structures. The blended structure that is chosen can offer flexibility (Graham, 2006), but in this case the chosen blended structure impeded flexibility in both the where and when of learning. Comparable contradictions are found often (Willems, 2005). Barnett (2014) concluded that "all too often ... decisions may be taken ... concerning 'flexibility' that are perhaps not always accompanied by a thinking through of the unintended consequences of action" (p. 19). Furthermore, the description of the curriculum's rationale left room for varying, even contradictory, interpretations, indicating the existence of disconnected views. Flexibility in Waterfront's curriculum manifests itself at a program level, with the rationale providing orientation. Although more teacher educators expressed their perceptions at a program level, only one of them explicitly mentioned the rationale about flexibility, in the sense that this was missing. Besides the variety of interpretations, an unclear or missing rationale makes it difficult to get an overview of the curriculum as a whole.

This study offers insights about how teachers perceive the implementation of a curriculum innovation, which is in line with Tucker and Morris' (2011) appeal for articulating the views and concerns of teachers.

First, this study showed that from a teacher's point of view, teacher-related conditions especially affect the realisation of flexibility in a blended curriculum, namely, teachers' attitudes, skills, and knowledge. Our finding that a teacher's attitude towards curriculum flexibility could either foster or inhibit (further) enactment of flexibility, subscribes to the importance of the time needed for sense-making in implementing an innovation successfully (cf. Coburn et al., 2012; Luttenberg et al., 2013). With regard to teachers' skills and knowledge, our findings confirm conclusions about teachers not being prepared (sufficiently) for developing and enacting flexibility (Boelens et al., 2017; Severiens et al., 2014) in a blended curriculum (Gerbic, 2011).

Second, the teacher educators perceived the context-related conditions as not (yet) ready for flexibility, because they experienced several institutional structures that impeded flexibility. Regularly, the teacher is blamed when curriculum innovations are not (completely) realised, but teachers have a limited space in which they must function (cf. Priestley, Biesta, Philippou, \& Robinson, 2015). The teacher educators' perceptions support claims that elements in this context may restrict offering flexibility (Tucker \& Morris, 2011). Barnett (2014) and Willems (2005) also signaled that flexible intentions may turn out to be inflexible in practice, which was the case in our study due to the blended structure chosen. Furthermore, not enough 
time was provided; this conclusion frequently occurs in research about curriculum innovations (cf. Graham et al., 2013).

Third, the teacher educators in our study subscribed to the relevance of possessing study skills that foster self-regulation (Boelens et al., 2017; Owston et al., 2013); at the same time, they assumed that students often lack these skills. However, in our study teacher educators especially linked the relevance of these skills to the curriculum's adaptability and to beginning/younger students.

Finally, the study showed that the conditions that affected flexibility in the blended curriculum lead, when perceived negatively, to several tensions. Essentially, these tensions reflected how aspects of teachers' professional identity are under pressure in the context of a curriculum change. According to Wiesenberg and Stacey (2008), many teachers try to maintain their routines and transfer them to their new (blended) practice, which might explain why the online parts of Waterfront's blended structure were merely a digital counterpart of $\mathrm{f} 2 \mathrm{f}$ lessons. Trying to maintain existing routines might also be an indication of how teachers solved their personal, practical concerns (about time, energy, and workload) in relation to enacting flexibility. For instance, Ulrike mentioned that redeveloping her courses into (more) flexible ones would consumes time and energy; Kevin stated that allowing room for choices implies an increase of workload; and Tinus concluded, "When all is fixed, it's just one way of doing things, it's more workable"). In other words, often the teacher educator's existing frame of reference was leading, instead of the flexible blended curriculum's frame of reference. Therefore, teacher-related tensions indicate that decisions were made and activities were undertaken that were probably not in line with the rationale, thus undermining the intentions about flexibility (Ketelaar et al., 2012; Luttenberg et al., 2013). Remarkably, the tensions that were identified related barely to the curriculum's pedagogical responsiveness. This makes sense, because traditionally, the space to show pedagogical responsiveness belongs to the professionalism of an individual teacher and is not seen as a responsibility of the team.

\section{Limitations and suggestions for future research}

From a methodological point of view, it should be taken into account that this was a small case study following the implementation of a flexible curriculum at one teacher education institute. A replication study could add strength to our conclusions. This could also remedy a possible bias: By being a colleague of Waterfront's teacher educators, the researcher could have been an influential factor herself. However, this possible bias was prevented by thoroughly discussing the analyses with researchers who were not involved with Waterfront College. This study looked at the perceptions of teachers on a team level. Future research could focus on the individual teacher level to add to our understanding about curriculum flexibility. Furthermore, flexibility could be supported by looking at the curriculum as a process instead of a predetermined product, as Boomer (1992) proposed. Future research could focus on whether such a stance leads to education that truly revolves around the student and his or her individual needs.

\section{Recommendations}

Finally, to prevent the occurrence of tensions that were identified, we suggest the following recommendations:

(1) Think thoroughly through what flexibility means.

(a) The institution should align structures/regulations with characteristics of flexibility (tension 4).

(b) The design team needs to decide carefully on the way the communication takes place in the online part of the curriculum. Especially for realising accessibility, asynchronous communication seems more appropriate than synchronous communication (Smits, 2012; tension 5).

(2) Organise meetings with all stakeholders about the intentions of the curriculum innovation and the curriculum rationale to prevent the development of disconnected views (tensions 1,6).

(3) Offer support to teachers and students so that they can function appropriately in a flexible blended curriculum (tensions 2, 7). 


\section{Acknowledgements}

This study was supported by the Netherlands Organization for Scientific Research (NWO).

\section{References}

Baran, E., Correia, A.-P., \& Thompson, A. (2011). Transforming online teaching practice: Critical analysis of the literature on the roles and competencies of online teachers. Distance Education, 32(3), 421-439. https://doi.org/10.1080/01587919.2011.610293

Baran, E., Correia, A.-P., \& Thompson, A. D. (2013). Tracing successful online teaching in higher education: Voices of exemplary online teachers. Teachers College Record, 115(3), 1-41. Retrieved from https://www.tcrecord.org/library/abstract.asp?contentid=16896

Barnett, R. (2014). Conditions of flexibility securing a more responsive higher education system. York, UK: The Higher Education Academy.

Boelens, R., De Wever, B. De, \& Voet, M. (2017). Four key challenges to the design of blended learning: A systematic literature review. Educational Research Review, 22, 1-18. https://doi.org/10.1016/j.edurev.2017.06.001

Boomer, G. (1992). Negotiating the curriculum reformulated. In G. Boomer, N. Lester, C. Onore, \& J. Cook (Eds.), Negotiating the curriculum: Educating for the 21st century (pp. 276-289). London, UK: Falmer Press.

Carlsen, A., Holmberg, C., Neghina, C., \& Owusu-Boampong, A. (2016). Closing the gap: Opportunities for distance education to benefit adult learners in higher education. Hamburg, Germany: UNESCO Institute for Lifelong Learning.

Cheong, K. (2013). Flexible learning: Dimensions and learner preferences. In Leveraging the Power of Open and Distance Learning (ODL) for Building a Divergent Asia-Today's Solutions and Tomorrow's Vision. Proceedings of the 27th International Conference of the Asian Association of Open Universities (pp. 1-8). Islamabad, Pakistan: Asian Association of Open Universities.

Coburn, C. E., Russell, J. L., Kaufman, J. H., \& Stein, M. K. (2012). Supporting sustainability: Teachers' advice networks and ambitious instructional reform. American Journal of Education, 119(1), 137182. https://doi.org/10.1086/667699

Collis, B. A., \& Moonen, J. (2001). Flexible learning in a digital world: Experiences and expectations. London, UK: Kogan Page Ltd.

Conceição, S. C. O. (2006). Faculty lived experiences in the online environment. Adult Education Quarterly, 57(I), 26-45. https://doi.org/10.1177/1059601106292247

Demedts, L., Raes, F., Spittaels, O., Lust, G., \& Van Puyenbroeck, H. (2015). De docent als sleutelfiguur bij blended learning [Teachers as key figures in blended learning]. TheMa, 1(1), 23-28.

Gerbic, P. (2011). Teaching using a blended approach - what does the literature tell us? Educational Media International, 48(3), 221-234. https://doi.org/10.1080/09523987.2011.615159

Graham, C. R. (2006). Blended learning systems: Definition, current trends, and future directions. In C. J. Bonk \& C. R. Graham (Eds.), Handbook of blended learning: Global perspectives, local designs (pp. 3-21). San Francisco, CA: Jossey-Bass/Pfeiffer.

Graham, C. R., Woodfield, W., \& Harrison, J. B. (2013). A framework for institutional adoption and implementation of blended learning in higher education. Internet and Higher Education, 18, 4-14. https://doi.org/10.1016/j.iheduc.2012.09.003

Halverson, L. R., Graham, C. R., Spring, K. J., Drysdale, J. S., \& Henrie, C. R. (2014). Internet and higher education: A thematic analysis of the most highly cited scholarship in the first decade of blended learning research. Internet and Higher Education, 20, 20-34. https://doi.org/10.1016/j.iheduc.2013.09.004

Hampel, R., \& Stickler, U. (2005). New skills for new classrooms: Training tutors to teach languages online. Computer Assisted Language Learning, 18(4), 37-41. https://doi.org/10.1080/09588220500335455

Hill, J. R. (2006). Flexible learning environments: Leveraging the affordances of flexible delivery and flexible learning. Innovative Higher Education, 31(3), 187-197. https://doi.org/10.1007/s10755-0069016-6

Hoy, W. K., \& Tarter, C. J. (2011). Power principles for educational leaders: Research into practice. International Journal of Educational Management, 25(2), 124-133. https://doi.org/10.1108/09513541111107551 
Jones, N., \& Lau, A. M. S. (2010). Blending learning: Widening participation in higher education. Innovations in Education and Teaching International, 47(4), 405-416. https://doi.org/10.1080/14703297.2010.518424

Jonker, H., März, V., \& Voogt, J. (2018). Curriculum flexibility in a blended curriculum. In T. Bastiaens et al. (Eds.), Proceedings of EdMedia: World Conference on Educational Media and Technology (pp. 459-464). Waynesville, NC: Association for the Advancement of Computing in Education. Retrieved from https://www.learntechlib.org/p/184231/

Ketelaar, E., Beijaard, D., Boshuizen, H. P., \& den Brok, P. J. (2012). Teachers' positioning towards an educational innovation in the light of ownership, sense-making and agency. Teaching and Teacher Education, 28(2), 273-282. https://doi.org/10.1016/j.tate.2011.10.004

Luttenberg, J., Van Veen, K., \& Imants, J. (2013). Looking for cohesion: The role of search for meaning in the interaction between teacher and reform. Research Papers in Education, 28(3), 289-308. https://doi.org/10.1080/02671522.2011.630746

Miles, M. B., \& Huberman, A. M. (1994). Qualitative data analysis: An expanded sourcebook (2nd ed.). Thousand Oaks, CA: Sage.

Mishra, P., \& Koehler, M. J. (2006). Technological pedagogical content knowledge: A framework for teacher knowledge. Teachers College Record, 108(6), 1017-1054. Retrieved from https://www.tcrecord.org/content.asp?contentid=12516

Morgan, M. (2013). Student diversity in higher education. In M. Morgan (Ed.), Supporting student diversity in higher education: A practical guide (pp. 10-22). New York, NY: Routledge.

Nikolov, R., Lai, K. W., Sendova, E., \& Jonker, H. (2018). Distance and flexible learning in the twentyfirst century. In J. M. Voogt, G. A. Knezek, R. Christensen, \& K. Lai (Eds.), Second handbook of information technology in primary and secondary education (pp. 1-16). Cham, Switzerland: Springer International Handbooks of Education. https://doi.org/10.1007/978-3-319-53803-7 45-2

Organisation for Economic Cooperation and Development. (2010). Educating teachers for diversity. Paris, France: OECD Publishing. https://doi.org/10.1787/20769679

Owston, R., York, D., \& Murtha, S. (2013). Student perceptions and achievement in a university blended learning strategic initiative. The Internet and Higher Education, 18, 38-46. https://doi.org/10.1016/j.iheduc.2012.12.003

Priestley, M., Biesta, G., Philippou, S., \& Robinson, S. (2015). The teacher and the curriculum: Exploring teacher agency. In S. Wyse, L. Hayward, \& J. Pandya (Eds.), The Sage handbook of curriculum, pedagogy and assessment (pp. 78-91). London, UK: Sage.

Rao, K., \& Meo, G. (2016). Using universal design for learning to design standards-based lessons. $S A G E$ Open, 6(4), 1-12. https://doi.org/10.1177/2158244016680688

Redecker, C., Leis, M., Leendertse, M., Punie, Y., Gijsbers, G., Kirschner, P., ... Hoogveld, B. (2010). The future of learning: New ways to learn new skills for future jobs. Results from an online expert consultation. Luxembourg City, Luxembourg: European Commission.

Saldaña, J. (2011). Fundamentals of qualitative research. New York, NY: Oxford University Press.

Severiens, S., Wolff, R., \& Van Herpen, S. (2014). Teaching for diversity: a literature overview and an analysis of the curriculum of a teacher training college. European Journal of Teacher Education, 37(3), 295-311. https://doi.org/10.1080/02619768.2013.845166

Siemens, G. (2005). Connectivism: A learning theory for the digital age. International Journal of Instructional Technology and Distance Learning, 2(1), 3-10. Retrieved from http://www.itdl.org/Journal/Jan 05/article01.htm

Smits, A. E. H. (2012). Ontwerp en implementatie van de masteropleiding Special Educational Needs via e-learning [Design and implementation of the master Special Educational Needs through e-learning]. Doctoral dissertation. Enschede, Netherlands: University of Twente. https://doi.org/10.3990/1.9789036533508

Smits, A. E. H., \& Voogt, J. M. (2017). Elements of satisfactory online asynchronous teacher behaviour in higher education. Australasian Journal of Educational Technology, 33(2), 97-114. https://doi.org/10.14742/ajet.2929

Tondeur, J., Van Braak, J., Ertmer, P. A., \& Ottenbreit-Leftwich, A. (2017). Understanding the relationship between teachers' pedagogical beliefs and technology use in education: A systematic review of qualitative evidence. Educational Technology Research and Development, 65(3), 555-575. https://doi.org/10.1007/s11423-016-9481-2

Tucker, R., \& Morris, G. (2011). Anytime, anywhere, anyplace: Articulating the meaning of flexible delivery in built environment education. British Journal of Educational Technology, 42(6), 904-915. https://doi.org/10.1111/j.1467-8535.2010.01138.x 
UNESCO. (2009). Policy guidelines on inclusion in education. Paris, France: Author.

Van den Akker, J. (2010). Building bridges: how research may improve curriculum policies and classroom practices. In S. Stoney (Ed.), Beyond Lisbon 2010: Perspectives from research and development for education policy in Europe (pp. 177-195). Slough, UK: National Foundation for Educational Research.

Wiesenberg, F., \& Stacey, E. (2008). Teaching philosophy: Moving from face-to-face to online classrooms. Canadian Journal of University Continuing Education, 34(1), 63-79. https://doi.org/10.21225/D5JP4G

Willems, J. (2005). Flexible learning: Implications of "when-ever", "where-ever" and "what-ever." Distance Education, 26(3), 429-435. https://doi.org/10.1080/01587910500291579

Corresponding author: Herma Jonker, h.jonker@windesheim.nl

Copyright: Articles published in the Australasian Journal of Educational Technology (AJET) are available under Creative Commons Attribution Non-Commercial No Derivatives Licence (CC BY-NC-ND 4.0). Authors retain copyright in their work and grant AJET right of first publication under CC BY-NC-ND 4.0.

Please cite as: Jonker, H., März, V., \& Voogt, J. (2020). Curriculum flexibility in a blended curriculum. Australasian Journal of Educational Technology, 36(1), 68-84. https://doi.org/10.14742/ajet.4926 


\section{Appendix: Codebook interviews}

\begin{tabular}{|c|c|c|c|c|c|c|c|}
\hline \multicolumn{8}{|c|}{ CODING SCHEME (flexibility in) INTENDED - FORMAL - PERCEIVED CURRICULUM } \\
\hline \multicolumn{2}{|c|}{ flexibility } & \multirow{2}{*}{\begin{tabular}{|l|} 
curriculum \\
Intented
\end{tabular}} & & \multirow{2}{*}{ 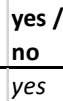 } & \multirow{2}{*}{$\begin{array}{l}\text { curriculum elements } \\
\mathrm{xxx}\end{array}$} & \multicolumn{2}{|l|}{ influential conditions } \\
\hline \multirow{32}{*}{\begin{tabular}{l|l|}
1 & What \\
2 & How \\
3 & Where \\
4 & When
\end{tabular}} & & & & & & \multirow{11}{*}{ (open explanation) } & \\
\hline & & & & \multirow{10}{*}{ no } & Expected more/less in .. & & \\
\hline & & & & & A. aims/objectives & & \\
\hline & & & & & B. content & & \\
\hline & & & & & C. assessment & & \\
\hline & & & & & D. learning activities & & \\
\hline & & & & & E. resources & & \\
\hline & & & & & F. grouping & & \\
\hline & & & & & G. teacher roles & & \\
\hline & & & & & H. learning environment & & \\
\hline & & & & & J. time & & \\
\hline & & Documented & & yes & $x x x$ & & \\
\hline & & & & \multirow{10}{*}{ no } & Different practice in .. & & \\
\hline & & & & & A. aims/objectives & Due to factors in / & \\
\hline & Adapt1 & & & & B. content & characteristics of the .. & o. not a factor \\
\hline & Adapt2 & & & & C. assessment & a. context (organizational) & i. outside Univ. $\quad$ ii. Univ. \\
\hline & Access1 & & & & D. learning activities & b. content (programmatic) & iii. Waterfront iv. team \\
\hline & Access2 & & & & E. resources & c. teacher (pedagogical) & v. knowledge vi. skills \\
\hline & & & & & F. grouping & d. student (pedagogical) & vii. attitude \\
\hline & & & & & G. teacher roles & x. other & \\
\hline & & & & & H. learning environment & & \\
\hline & & & & & J. time & & \\
\hline & & \multirow[t]{10}{*}{ Perceived } & & \multirow{9}{*}{ yes } & A. aims/objectives & & \\
\hline & & & & & B. content & Restricted by factors in / & \\
\hline & & & 3.1 & & C. assessment & characteristics of the .. & o. not a factor \\
\hline & & & More flex & & D. learning activities & a. context & i. outside Univ \\
\hline & & & possible... & & E. resources & b. content & iii. Waterfront iv. team \\
\hline & & & 3.2 & & F. grouping & c. teacher & v. knowledge vi. skills \\
\hline & & & More flex & & G. teacher roles & d. student & vii. attitude \\
\hline & & & necessary & & H. learning environment & $x$. other & \\
\hline & & & & & J. time & & \\
\hline & & & & no & $x x x$ & & \\
\hline
\end{tabular}

